\title{
FORMULASI DAN EVALUASI TABLET EFFERVESCENT DARI EKSTRAK BUAH TAMPOI (Baccaurea Macrocarpa)
}

\author{
Formulation and Evaluation of Effervescent Tablets from Tampoi Fruits Exstract \\ (Baccaurea Macrocarpa)
}

\author{
Ika Avrilina Haryono ${ }^{*}$ \\ Noval' \\ ${ }^{*}$ Health Faculty, Sari Mulia \\ University, Banjarmasin City, \\ South Borneo 70238, Indonesia
}

*email: ika.avrilina@yahoo.com

Kata Kunci:

Buah Tampoi

Antioksidan

Tablet Effervescent

\author{
Keywords: \\ Tampoi Fruits \\ Antioksidan \\ Effevescent Tablets
}

\begin{abstract}
Abstrak
Tampoi merupakan satu dari tumbuhan yang banyak ditemukan di daerah Kalimantan Timur, memiliki kandungan metabolik sekunder berupa saponin, flavonoid dan alkaloid, serta memiliki aktifitas antioksidan. Antioksidan yang dihasilkan tubuh manusia tidak mencukupi untuk melawan radikal bebas, oleh karena itu tubuh memerlukan asupan antioksidan dari luar, sehingga untuk membantu meningkatkan minat konsumsi masyarakat, peneliti tertarik untuk membuat sediaan dalam bentuk ekstrak dan diformulasikan sebagai tablet effervescent dari ekstrak buah tampoi yang bermanfaat sebagai antioksidan dan peningkatan daya tahan tubuh. Tujuan dari penelitian ini yaitu untuk mengetahui formula yang baik dalam pembuatan tablet effervescent dari ekstrak buah tampoi dengan variasi PVP K30 sebagai bahan pengikat. Pembuatan tablet menggunakan metode kempa langsung dengan evaluasi serbuk effervescent meliputi uji sudut diam, kecepatan alir, pengetapan, kompresibilitas dan kelembaban serbuk. Evaluasi tablet effervescent meliputi uji organoleptik, uji keseragaman bobot, uji kerapuhan tablet, uji kekerasan tablet dan uji waktu larut tablet. Hasil penelitian diperoleh pada evaluasi serbuk effervescent uji sudut diam sudah memenuhi persyaratan, adapun pada uji kecepatan alir, pengetapan, kompresibilitas dan kelembaban serbuk belum memenuhi persyaratan. Hasil evaluasi fisik uji keseragaman bobot tablet pada $\mathrm{FI}$ dan F2 sudah sesuai persyaratan, uji kerapuhan tablet pada F3 dan F4 sudah memenuhi persyaratan, pada uji kekerasan tablet F3 sudah memenuhi persyaratan dan pada uji waktu larut tablet dihasilkan semua formula sudah memenuhi persyaratan dengan formula paling baik yaitu FI yang memiliki waktu larut tablet paling cepat. Kesimpulan penelitian dari evaluasi waktu larut yang merupakan parameter utama sediaan tablet effervescent ekstrak buah tampoi didapatkan formula yang paling baik yaitu FI dengan konsentrasi PVP K30 yaitu $0,5 \mathrm{mg}$ dihasilkan waktu larut tablet selama 01.99 menit.
\end{abstract}




\section{PENDAHULUAN}

Perkembangan teknologi menjadi salah satu faktor peneliti dalam meneliti untuk penemuan obat baru. Potensi obat bahan alam di Indonesia sangat besar, Indonesia merupakan salah satu negara penghasil terbesar tanaman dengan bahan baku obat dan penggunaan bahan alam sebagai obat juga sudah cukup membudidaya dimasyarakat (Noval et al., 202I).

Salah satu bahan alam yang dapat dijadikan bahan baku obat adalah Baccaurea macrocarpa atau yang lebih dikenal dengan nama daerah Tampoi, Kapul, atau Terai merupakan satu dari tumbuhan yang banyak ditemukan di daerah Kalimantan (Heagens, 2000). Tanaman ini banyak ditemukan di hutan atau dipekarangan rumah dan buah ini banyak sekali mengandung nutrisi yang bermanfaat untuk tubuh (Haryono et al., 202I).

Pada peneliti sebelumnya diperoleh informasi bahwa ekstrak methanol buah tampoi (Baccaurea macrocapa) memiliki kandungan metabolic sekunder berupa saponin, flavonoid dan alkaloid. Ekstrak tersebut memiliki aktifitas sebagai antioksidan sebesar IC50

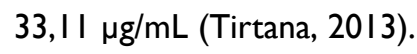

Selain sebagai antioksidan, kulit buah kapul juga mengandung golongan senyawa alkaloid, polifenol, dan flavonoid yang berfungsi untuk menghambat antibakteri dan pertumbuhan E. coli dan S. aureus. Buah kapul juga memiliki kandungan nutrisi yang baik, antara lain serat $2,2 \%$, lemak $I, I \%$, abu $0,9 \%$, karbohidrat $34,6 \%$, protein 1,5\%, kadar air 61,9\%, dan vitamin C I,5\% (Akhmadi, 20I5).

Apalagi dimasa pandemi covid-19 saat ini, menjaga imunitas tubuh sangat diperlukan agar terhindar dari paparan virus. Selain berperan melindungi organ tubuh dari radikal bebas juga membantu meningkatkan imunitas tubuh. Antioksidan yang dihasilkan tubuh manusia tidak mencukupi untuk melawan radikal bebas, oleh karena itu tubuh memerlukan asupan antioksidan dari luar. Mengingat pentingnya menjaga tubuh, kita juga dituntut untuk berinovasi dan memberikan nilai manfaat kepada masyarakat, maka untuk membantu meningkatkan minat konsumsi masyarakat, peneliti tertarik untuk membuat sediaan dalam bentuk ekstrak dan diformulasikan sebagai tablet effervescent dari ekstrak buah tampoi yang bermanfaat sebagai antioksidan dan peningkatan daya tahan tubuh (Nastiti, et al., 202l).

Tablet effervescent merupakan sediaan tablet yang dibuat dengan cara pengempaan bahan aktif dengan campuran asam organik dan natrium bikarbonat (Noval, 202I). Tablet effervescent lebih disukai karena praktis dan cepat larut dalam air tanpa harus mengaduk, memberikan efek menyegarkan serta dosis obat dapat disesuaikan (Lestari dan Natalia, 2007) (Noval \& Malahayati, 202I). Tablet effervescent juga dalam pemilihan polimer yang tepat akan menghasilkan sediaan yang stabil dan memiliki mutu yang baik (Syahrina \& Noval, 2021). Polimer yang digunakan adalah PVP K30 karena memiliki kelebihan dalam menghasilkan sediaan yang dapat cepat terlarut (Indartantri et al., 202I) (Novia \& Noval, 202I).

Tujuan penelitian ini adalah mengetahui formula yang baik dalam pembuatan tablet effervescent dari ekstrak buah tampoi dengan variasi PVP K30 sebagai pengikat.

\section{METODOLOGI}

\section{Alat dan Bahan}

Alat yang digunakan dalam penelitian ini meliputi gelas, cawan penguap, water bath, blender, alat maserasi, neraca elektrik, corong, stopwatch, pengayak 14 mesh, mesin kempa tablet single punch, friability tester, jangka sorong, hardness tester, oven dan hygrotermometer.

Bahan yang digunakan pada penelitian ini buah tampoi, etanol 70\%, natrium bikarbonat, asam sitrat, asam tartrat, PVP K30, Laktosa, Talkum, Mg stearat, manitol, vanili (perasa), pewarna makanan, alumunium foil, plastic wrap, kertas saring, kapas, label, tissu, serbet.

\section{Metode Penelitian}


Sampel buah tampoi (Baccaurea macrocarpa) didapatkan dari Kabupaten Tabalong, Kalimantan Selatan.

\section{Pembuatan Ekstrak Buah Tampoi}

Ekstraksi menggunakan metode maserasi. Tahapan ekstraksi adalah sebagai berikut:

I. Simplisia dari buah tampoi (Baccaurea macrocarpa)

2. Dimasukkan etanol ke dalam bejana sampai merendam simplisia setinggi $2-3 \mathrm{~cm}$

3. Bejana maserasi ditutup dan dibiarkan rendaman selama 3 hari sambil sesekali di aduk

4. Cairan hasil ekstraksi dikeluarkan dari bejana dengan disaring

5. Filtrat kemudian diuapkan menggunakan rotary evaporator sampai didapatkan ekstrak kental.

Tabel I. Formula sediaan tablet effervescent ekstrak buah tampoi

\begin{tabular}{lcccc}
\hline \multirow{2}{*}{ Bahan (Mg) } & \multicolumn{4}{c}{ Formula } \\
\cline { 2 - 5 } & I & II & III & IV \\
\hline Granul ekstrak buah tampoi & 68,5 & 67,2 & 64 & $5 \mathrm{I}$ \\
\hline PVP K30 & 0,5 & $\mathrm{I}, 8$ & 5 & $\mathrm{I}$ \\
\hline Asam sitrat & 35 & 35 & 35 & 35 \\
\hline Asam tartrat & 40 & 40 & 40 & 40 \\
\hline Natrium bikarbonat & 75 & 75 & 75 & 75 \\
\hline Mg. stearat & 3 & 3 & 3 & 3 \\
\hline Talkum & 20 & 20 & 20 & 20 \\
\hline Manitol & 50 & 50 & 50 & 50 \\
\hline Flavor & 8 & 8 & 8 & 8 \\
\hline Berat masing-masing tablet sebesar $300 \mathrm{mg}$ & & & \\
\hline
\end{tabular}

Prosedur Kerja Pembuatan tablet effervescent buah tampoi

I. Pembuatan granul effervescent

a. Ekstrak digranulasi dengan laktosa, dihasilkan granul ekstrak

b. Granul asam dibuat dengan mencampurkan granul ekstrak, asam sitrat, asam tartrat, dan sebagian PVP

c. Granul basa dibuat dengan mencampurkan natrium bikarbonat dengan sisa PVP

d. Proses pembuatan pada suhu dan kelembapan terjaga, dimana PVP dalam bentuk kering dan ditambahkan etanol $70 \%$ tetes demi tetes e. Masa di ayak menggunakan ayakan 14 mesh dan dikeringkan dalam oven pada suhu 4060 oC sampai kering

f. Granul ditambahkan talkum, mg stearat, perasa dan pewarna

2. Pemeriksaan sifat dan kecepatan alir granul effervescent

a. Penentuan sudut diam.

b. Pengukuran kecepatan alir, dilakukan dengan menuangkan granul secara perlahan-lahan melalui tepi corong yang ujungnya tertutup

3. Pembuatan Tablet Effervescent

a. Mengukur suhu ruangan di bawah $25 \circ \mathrm{C}$ dan kelembapan terjaga

b. Granul dimasukkan ke dalam mesin cetak single punch

c. Granul dialirkan dari hopper ke dalam lubang die dengan ukuran tertentu

d. Terbentuklah tablet sesuai bobot yang diinginkan

\section{Evaluasi sediaan tablet effervescent buah} tampoi

Tablet yang sudah dihasilkan diuji organoleptis, keseragaman ukuran, keseragaman bobot, kekerasan, friabilitas atau kerapuhan, dan uji wkatu melarut.

\section{HASIL DAN PEMBAHASAN}

\section{Hasil Penelitian}

\section{Evaluasi Serbuk Effervescent}

Evaluasi serbuk effervescent bertujuan untuk memastikan bahwa tiap formula memenuhi persyaratan preformulasi sediaan (Syahrina D \& Noval, 202I). Evaluasi serbuk effervescent yang dilakukan meliputi pengujian kecepatan alir, uji sudut diam, uji pengetapan, uji kompresibilitas dan uji kelembaban serbuk.

a. Kecepatan Alir

Hasil evaluasi kecepatan alir serbuk effervescent dapat dilihat pada tabel 2. di bawah. 
Tabel 2. Hasil kecepatan alir serbuk effervescent

\begin{tabular}{cc}
\hline Formulasi & Laju alir (detik) \\
\hline FI & 2 \\
F2 & 2 \\
F3 & 2 \\
F4 & 3
\end{tabular}

Hasil evaluasi kecepatan alir serbuk effervescent dapat dilihat pada tabel 2., dimana hasil dari tabel menunjukkan FI, F2, F3 kecepatan alir yang sama yaitu 2 detik dan F4 memiliki laju alir tertinggi yaitu 3 detik.

Uji kecepatan alir serbuk bertujuan untuk mengetahui kualitas serbuk effervescent karena kecepatan alir serbuk berpengaruh pada daya alir serbuk saat proses pencetakan tablet (Putra et al, 2019). Kecepatan alir dikatakan baik jika memiliki kecepatan alir tidak kurang dari 10 g/detik (Syahria D \& Noval, 202I). Berdasarkan penelitian menunjukkan hasil kecepatan alir pada FI, F2 dan F3 memiliki kecepatan alir yang baik dan memenuhi persyaratan dimana untuk serbuk 20 gram membentuk kecepatan alir selama 2 detik. Adapun pada F4 memiliki kecapatan alir 3 detik untuk 20 gram serbuk, dimana hasil tersebut belum memenuhi persyaratan kecepatan alir yang baik. Menurut persyaratan, kecepatan alir yang baik yaitu tidak kurang dari $10 \mathrm{~g} /$ detik (Syahrina D \& Noval, 2021). Kecepatan alir dipengaruhi oleh bentuk dan ukuran partikel, serbuk dengan ukuran dan bentuk partikel yang tidak seragam akan menghasilkan kecetapan alir yang kurang baik. Semakin seragam ukuran dan bentuk partikel dari serbuk, kecepatan alir yang dihasilkan juga akan semakin baik (Hermanto, 2019). Penambahan PVP K30 yang berperan sebagai pengikat juga bepengaruh pada kecepatan alir serbuk. PVP K30 akan berperan dalam meningkatkan ukuran partikel sehingga mampu menurunkan gaya kohesi yang akan menghasilkan kecepatan alir yang baik (Syahrina D \& Noval, 202I).

b. Sudut Diam
Hasil evaluasi sudut diam serbuk effervescent dapat dilihat pada tabel 3. di bawah.

Tabel 3. Hasil evaluasi sudut diam serbuk

\begin{tabular}{cc}
\multicolumn{2}{c}{ effervescent } \\
\hline Formulasi & Sudut diam $\left(^{\circ}\right)$ \\
\hline FI & 26,9 I \\
F2 & 25 \\
F3 & 25,47 \\
F4 & 24,30
\end{tabular}

Hasil evaluasi sudut diam serbuk effervescent dapat dilihat pada tabel 3., dimana hasil dari tabel menunjukkan FI memiliki nilai sudut diam tertinggi yaitu $26,91^{\circ}$ dan F4 memiliki nilai sudut diam terendah yaitu $24,30^{\circ}$.

c. Pengetapan

Hasil evaluasi pengetapan serbuk effervescent dapat dilihat pada tabel 4. di bawah.

Tabel 4. Hasil evaluasi sudut diam serbuk effervescent

\begin{tabular}{cc}
\hline Formulasi & Pengetapan (\%) \\
\hline FI & $\mathbf{8 , 4 4}$ \\
F2 & $\mathbf{8 , 4 6}$ \\
F3 & 14,83 \\
F4 & 21,65 \\
\hline
\end{tabular}

Hasil evaluasi pengetapan serbuk effervescent dapat dilihat pada tabel 4., dimana dari hasil gambar menujukkan F4 memiliki nilai pengetapan tertinggi yaitu $21,65 \%$ dan $\mathrm{FI}$ memiliki nilai kompresibilitas terendah yaitu $8,44 \%$.

d. Kompresibilitas

Hasil evaluasi kompresibilitas serbuk effervescent dapat dilihat pada tabel 5. di bawah.

Tabel 5. Hasil kompresibilitas serbuk effervescent

\begin{tabular}{cc}
\hline Formulasi & Laju alir (detik) \\
\hline FI & $\mathbf{7 , 9 3}$ \\
F2 & 9,37 \\
F3 & 13,84 \\
F4 & 22,05
\end{tabular}

Hasil evaluasi kompresibilitas serbuk effervescent dapat dilihat pada tabel 5., dimana dari hasil gambar menujukkan F4 memiliki nilai pengetapan tertinggi yaitu $22,05 \%$ dan $\mathrm{FI}$ memiliki nilai kompresibilitas terendah yaitu 7,93\%.

e. Kelembaban Serbuk (Moisture Content) Hasil evaluasi Moisture Content (MC) serbuk effervescent dapat dilihat pada tabel 5. di bawah ini 
Tabel 6. Hasil kelembaban serbuk effervescent

\begin{tabular}{cccc}
\hline Formulasi & $\begin{array}{c}\text { Bobot } \\
\text { sebelum } \\
\text { pengeringan } \\
\mathbf{( g )}\end{array}$ & $\begin{array}{c}\text { Bobot } \\
\text { setelah } \\
\text { pengeringan } \\
\mathbf{( g )}\end{array}$ & \%MC \\
\hline FI & 14,775 & 12,332 & 19,81 \\
F2 & 14,640 & 12,159 & 20,40 \\
F3 & 14,600 & 12,088 & 20,78 \\
F4 & 15,050 & 13,835 & 8,78 \\
\hline Hasil evaluasi & Moisture & Content $($ MC) & dapat \\
dilihat pada gambar 6., dimana hasil dari gambar \\
menunjukkan F3 memiliki nilai MC tertinggi yaitu \\
20,78\% dan F4 memiliki nilai MC terendah yaitu \\
8,78\%.
\end{tabular}

\section{Evaluasi Tablet Effervescent}

Tablet yang dihasilkan pada tiap formula adalah 50 tablet effervescent, dengan total keseluruhan tablet untuk 4 formula yaitu 200 tablet effervescent.

a. Organoleptis

Tabel 7. Hasil evaluasi organoleptis tablet effervescent

\begin{tabular}{|c|c|c|c|c|}
\hline \multirow{2}{*}{ Formula } & \multicolumn{4}{|c|}{ Pemeriksaan Organoleptis } \\
\hline & Bentuk & Bau & Warna & Rasa \\
\hline FI & Bulat pipih & Khas & $\begin{array}{l}\text { Coklat } \\
\text { muda }\end{array}$ & $\begin{array}{c}\text { Sedikit } \\
\text { pahit }\end{array}$ \\
\hline F2 & Bulat pipih & Khas & $\begin{array}{l}\text { Coklat } \\
\text { muda }\end{array}$ & $\begin{array}{c}\text { Sedikit } \\
\text { pahit }\end{array}$ \\
\hline F3 & Bulat pipih & Khas & $\begin{array}{l}\text { Coklat } \\
\text { muda }\end{array}$ & $\begin{array}{c}\text { Sedikit } \\
\text { pahit }\end{array}$ \\
\hline $\mathrm{F} 4$ & Bulat pipih & Khas & $\begin{array}{l}\text { Coklat } \\
\text { muda }\end{array}$ & $\begin{array}{c}\text { Sedikit } \\
\text { pahit }\end{array}$ \\
\hline
\end{tabular}

Berdasarkan tabel 7. di atas dapat dilihat bahwa semua hasil evaluasi organoleptis memiliki kesamaan dari FI, F2, F3 dan F4 dengan bentuk bulat pipih, berbau khas, berwarna coklat muda dan rasa sedikit pahit.

b. Keseragaman bobot

Tabel 8. Hasil evaluasi keseragaman bobot tablet FI

\begin{tabular}{cccc}
\hline \multicolumn{4}{l}{ Bobot tablet $(\mathbf{m g})$} \\
\hline Tablet I & 290 & Tablet I I & 297 \\
Tablet 2 & 298 & Tablet I2 & 292 \\
Tablet 3 & 288 & Tablet I3 & 294 \\
Tablet 4 & 290 & Tablet I4 & 304 \\
Tablet 5 & 288 & Tablet I5 & 290 \\
Tablet 6 & 294 & Tablet I6 & 296 \\
Tablet 7 & 284 & Tablet I7 & 29 I \\
Tablet 8 & 300 & Tablet I8 & 299 \\
Tablet 9 & 295 & Tablet I9 & 270
\end{tabular}

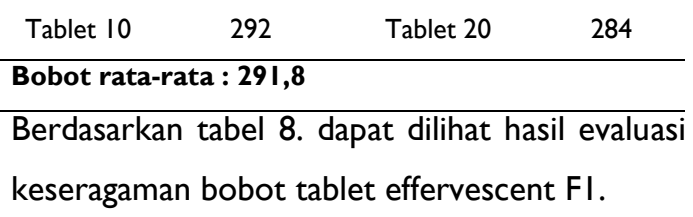

Kolom A : 7,5\% = 21,88 mg, rentang bobot tablet effervescent $=264 \mathrm{mg}-313 \mathrm{mg}$.

Kolom B: $15 \%=43,77 \mathrm{mg}$, rentang bobot tablet effervescent $=248-335 \mathrm{mg}$.

Tabel 9. Hasil evaluasi keseragaman bobot tablet F2

\begin{tabular}{lccc}
\hline \multicolumn{4}{c}{ Bobot tablet (mg) } \\
\hline Tablet I & 289 & Tablet II & 294 \\
Tablet 2 & 285 & Tablet I2 & 290 \\
Tablet 3 & 285 & Tablet I3 & 282 \\
Tablet 4 & 293 & Tablet I4 & 295 \\
Tablet 5 & 287 & Tablet I5 & 287 \\
Tablet 6 & 289 & Tablet I6 & 289 \\
Tablet 7 & 29 I & Tablet I7 & 295 \\
Tablet 8 & 289 & Tablet I8 & 28 I \\
Tablet 9 & 287 & Tablet I9 & 285 \\
Tablet I0 & 286 & Tablet 20 & 289 \\
\hline Bobot rata-rata : 288,4 & \\
\hline Berdasarkan tabel 9. dapat dilihat hasil evaluasi \\
keseragaman bobot tablet effervescent F2. \\
Kolom A : 7,5\% = 21,63 mg, rentang bobot \\
tablet effervescent = 266 mg-3 I0 mg. \\
Kolom B : I5\% = 43,26 mg, rentang bobot \\
tablet effervescent = 245 mg-33 I mg.
\end{tabular}

Tabel I0. Hasil evaluasi keseragaman bobot tablet F3

\begin{tabular}{llll}
\hline \multicolumn{4}{l}{ Bobot tablet (mg) } \\
\hline Tablet I & 3I4 & Tablet II & 289 \\
Tablet 2 & 305 & Tablet I2 & 30 I \\
Tablet 3 & 299 & Tablet I3 & 30 I \\
Tablet 4 & 296 & Tablet I4 & 303 \\
Tablet 5 & 297 & Tablet I5 & 31 I \\
Tablet 6 & 293 & Tablet I6 & 295 \\
Tablet 7 & 313 & Tablet I7 & 325 \\
Tablet 8 & 291 & Tablet I8 & 315 \\
Tablet 9 & 301 & Tablet I9 & 313 \\
Tablet I0 & 301 & Tablet 20 & 298 \\
\hline
\end{tabular}

Bobot rata-rata : 288,5

Berdasarkan tabel 10. dapat dilihat hasil evaluasi keseragaman bobot tablet effervescent F3.

Kolom $\mathrm{A}: 7,5 \%=21,63 \mathrm{mg}$, rentang bobot tablet effervescent $=266 \mathrm{mg}-310 \mathrm{mg}$.

Kolom B : $15 \%=43,26 \mathrm{mg}$, rentang bobot tablet effervescent $=245 \mathrm{mg}-33 \mathrm{I} \mathrm{mg}$ 
Tabel I I. Hasil evaluasi keseragaman bobot tablet F4

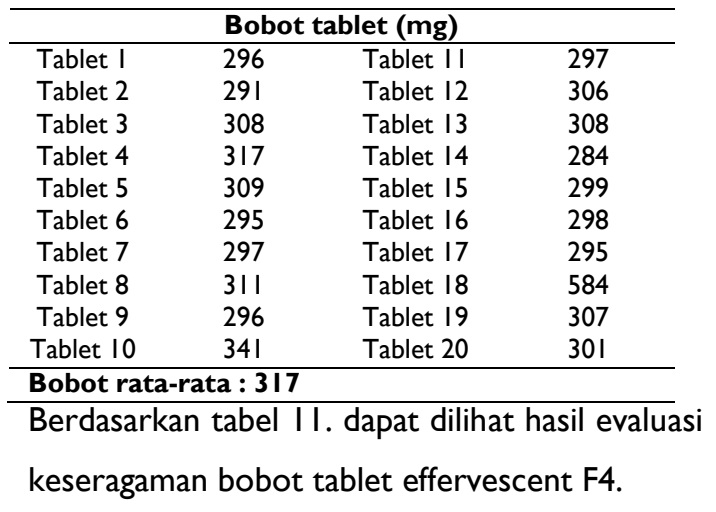

Kolom $A: 7,5 \%=23,77 \mathrm{mg}$, rentang bobot tablet effervescent $=293 \mathrm{mg}-340 \mathrm{mg}$.

Kolom B : $15 \%=47,55 \mathrm{mg}$, rentang bobot tablet effervescent $=269 \mathrm{mg}-364 \mathrm{mg}$.

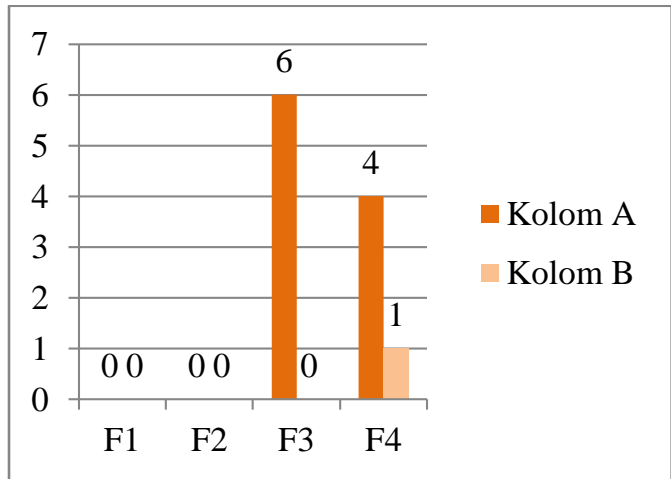

Gambar I. Hasil evaluasi keseragaman bobot

Berdasarkan gambar I. hasil evaluasi keseragaman bobot dapat dilihat pada F3 terdapat 6 tablet yang menyimpang dari kolom A, pada F4 terdapat 4 tablet yang menyimpang dari kolom A dan I tablet yang menyimpang dari kolom B. Adapun pada FI dan F2 tidak terdapat penyimpangan bobot tablet.

c. Kekerasan Tablet

Tabel I 2. Hasil evaluasi kekerasan tablet

\begin{tabular}{cc}
\hline Formula & Kekerasan $(\mathbf{k g})$ \\
\hline FI & 3,3 \\
F2 & 2 \\
F3 & 5,6 \\
F4 & 2,6
\end{tabular}

Berdasarkan tabel 12. hasil evaluasi kekerasan tablet dapat dilihat nilai kekerasan tablet tertinggi pada F3 dengan nilai kekerasan $5,6 \mathrm{~kg}$ dan nilai kekerasan tablet terendah pada F2 dengan nilai kekerasan tablet yaitu $2 \mathrm{~kg}$. d. Kerapuhan tablet

Tabel I3. Hasil evaluasi kerapuhan tablet

\begin{tabular}{cccc}
\hline Formula & $\begin{array}{c}\text { Bobot awal } \\
\mathbf{( g )}\end{array}$ & $\begin{array}{c}\text { Bobot } \\
\text { akhir } \mathbf{( g )}\end{array}$ & $\begin{array}{c}\text { Kerapuhan } \\
\text { (\%) }\end{array}$ \\
\hline FI & 2,90 & 2,87 & 1,03 \\
F2 & 2,90 & 2,87 & 1,03 \\
F3 & 2,99 & 2,97 & 0,66 \\
F4 & 3,02 & 3,01 & 0,33 \\
\hline
\end{tabular}

Berdasarkan tabel 13. hasil evaluasi kerapuhan tablet menunjukkan persentase kerapuhan tertinggi pada FI dan F2 dengan nilai kerapuhan I,03\% dan persentase kerapuhan terendah pada F4 yaitu dengan nilai kerapuhan $0,33 \%$.

e. Waktu Larut

Tabel I4. Hasil evaluasi waktu larut tablet effervescent

\begin{tabular}{cc}
\hline Formula & Waktu larut (Menit) \\
\hline FI & 01.99 \\
F2 & 02.25 \\
F3 & 02.70 \\
F4 & 04.03 \\
\hline
\end{tabular}

Berdasarkan tabel 14. hasil evaluasi waktu larut tablet dapat dilihat waktu larut tertinggi pada F4 dengan waktu larut selama 04.03 menit dan waktu larut terendah pada FI dengan waktu larut selama 01.99 menit.

\section{Pembahasan}

I. Evaluasi Serbuk Effervescent

Tablet effervescent merupakan sediaan tablet yang dibuat dengan cara mencetak campuran dari zat aktif serta asam-asam organik dan natrium karbonat yang membentuk suatu karbondioksida untuk proses pelarutan obat (Hermanto, 2019). Evaluasi serbuk effervescent perlu dilakukan untuk memastikan tiap formula memenuhi persyaratan preformulasi sediaan (Syahrina D \& Noval, 2021). Evaluasi serbuk effervescent meliputi uji kecepatan alir, uji sudut diam, uji pengetapan, uji kompresibilitas dan uji kelembaban serbuk (Moisture Content).

Uji kecepatan alir serbuk bertujuan untuk mengetahui kualitas serbuk effervescent karena kecepatan alir serbuk berpengaruh pada daya alir serbuk saat proses pencetakan tablet (Putra et al, 2019). Kecepatan alir dikatakan baik jika memiliki kecepatan alir tidak kurang dari 10 g/detik 
(Syahrina D \& Noval, 202I). Berdasarkan penelitian menunjukkan hasil kecepatan alir pada FI, F2 dan F3 memiliki kecepatan alir yang baik dan memenuhi persyaratan dimana untuk serbuk 20 gram membentuk kecepatan alir selama 2 detik. Adapun pada F4 memiliki kecapatan alir 3 detik untuk 20 gram serbuk, dimana hasil tersebut belum memenuhi persyaratan kecepatan alir yang baik. Menurut persyaratan, kecepatan alir yang baik yaitu tidak kurang dari $10 \mathrm{~g} /$ detik (Syahrina D \& Noval, 2021). Kecepatan alir dipengaruhi oleh bentuk dan ukuran partikel, serbuk dengan ukuran dan bentuk partikel yang tidak seragam akan menghasilkan kecetapan alir yang kurang baik. Semakin seragam ukuran dan bentuk partikel dari serbuk, kecepatan alir yang dihasilkan juga akan semakin baik (Hermanto, 2019). Penambahan PVP K30 yang berperan sebagai pengikat juga bepengaruh pada kecepatan alir serbuk. PVP K30 akan berperan dalam meningkatkan ukuran partikel sehingga mampu menurunkan gaya kohesi yang akan menghasilkan kecepatan alir yang baik (Syahrina D \& Noval, 202I).

Uji sudut diam dilakukan dengan mengukur tinggi dan jari-jari kerucut serbuk yang terbentuk pada uji kecepatan alir (Fatikha N, 2020). Sudut diam yang baik berada pada rentang $25^{\circ}-45^{\circ}$ (Ramadhani R.F, 2018). Berdasarkan penelitian hasil uji sudut diam menunjukkan pada FI yaitu $26,91^{\circ}, \mathrm{F} 2$ yaitu $25^{\circ}, \mathrm{F} 3$ yaitu $25,47^{\circ}$ dan F4 yaitu $24,30^{\circ}$. Semua formula memiliki sudut diam yang baik karena berada pada rentang $25^{\circ}-45^{\circ}$ (Noval, 202I). Derajat sudut diam dipengaruhi oleh kecepatan alir serbuk, kecepatan alir serbuk yang baik akan menghasilkan derajat sudut diam yang baik pula (Syahrina D \& Noval, 202I).

Uji pengetapan menggambarkan volume serbuk effervescent akibat hentakan ataupun getaran. Indeks pengetapan yang baik yaitu kurang dari 20\% (Ramadhani R.F, 20I8). Berdasarkan penelitian hasil uji pengetapan menunjukkan pada FI yaitu $8,44 \%$, F2 yaitu $8,46 \%$, F3 yaitu I4, 83\% dan F4 yaitu 2I,65\%. Pada FI, F2 dan F3 memenuhi persyaratan karna indeks pengetapan yang dihasilkan kurang dari 20\%. Adapun pada F4 tidak memenuhi persyaratan karena ketentuan indeks pengetapan yaitu $20 \%$. Indeks pengetapan dapat dipengaruhi oleh konsentrasi bahan pengikat, indeks pengetapan akan berbeda karena adanya konsentrasi bahan pengikat yang berbeda pula, dimana bahan pengikat berperan untuk mempertahankan kestabilan dan kekompakan serbuk ataupun granul (Ramadhani R.F, 2018).

Uji kompresibilitas menggambarkan sifat serbuk yang stabil dan kompak saat diberi tekanan pada proses pencetakan tablet, nilai kompresibilitas yang baik yaitu kurang dari $20 \%$, semakin kecil nilai kompresibilitas akan semakin baik kemampuan serbuk untuk mengalir (Noval et al, 202I). Berdasarkan penelitian hasil uji kompresibilitas menunjukkan pada $\mathrm{FI}$ yaitu 7,93\%, F2 yaitu 9,37\%, F3 yaitu 13,84\% dan F4 yaitu 22,05\%. Pada FI, F2 dan F3 sudah memenuhi persyaratan, adapun pada F4 belum memenuhi persyaratan karena menurut persyatan nilai kompresibilitas yang baik yaitu kurang dari 20\% (Noval et al, 202I). Nilai kompresibilitas dapat dipengaruhi oleh kelembaban serbuk, serbuk dengan kelembaban yang tinggi pada saat diberi tekanan atau getaran akan mengalami penurunan volume yang tinggi pula sehingga menghasilkan nilai kompresibilitas yang semakin besar (Fatikha N, 2020). Bentuk dan ukuran partikel serbuk juga berpengaruh pada nilai kompresibilitas, kompresibilitas yang baik ditunjukkan oleh bentuk dan ukuran partikel serbuk yang seragam sehingga akan mempermudah proses pencetakan dan 
menghasilkan tablet effervescent yang kompak pada saat dicetak (Hermanto, 2019).

Uji kelembaban serbuk bertujuan untuk mengetahui kadar air dari serbuk effervescent setelah mengalami proses pengeringan (Putra et al, 2019). Pengeringan dilakukan untuk mengontrol masa serbuk effervescent agar tidak mudah ditumbuhi mikroba ataupun jamur (Fathika N, 2020). Kelembaban serbuk effervescent yang baik yaitu kurang dari 5\% (Syahrina D \& Noval, 2021). Teori lain menyebutkan kelembaban serbuk yang baik yaitu kurang dari 10\% (BPOM RI, 20I5). Serbuk dengan kelembaban yang tinggi akan sulit untuk dikompresi karena massa akan lengket pada mesin cetak dan menyebabkan capping. Sedangkan jika kelembaban terlalu rendah akan menghasilkan tablet yang mudah rapuh karena daya ikat antar tablet yang terlalu rendah (Elisabeth $\mathrm{V}$ et al., 2018). Berdasarkan penelitian hasil uji kelembaban serbuk diperoleh pada $\mathrm{FI}$ yaitu $19,81 \%$, F2 yaitu $20,40 \%$, F3 yaitu $20,78 \%$ dan F4 yaitu $8,78 \%$. Hasil tersebut menunjukkan pada F4 sudah memenuhi kelembaban serbuk yang baik yaitu kurang dari 10\%, adapun pada FI, F2 dan F3 belum memenuhi persyaratan karena melebihi batas ketentuan kandungan lembab yaitu I0\% (BPOM RI, 20I5). Kandungan lembab di atas $10 \%$ dapat disebabkan tingginya degradasi dari sediaan, hal tersebut karena konsentrasi bahan pengikat yang terlalu rendah yang menyebabkan ukuran dan masa jenis sediaan juga kecil (Elisabeth $\mathrm{V}$ et al., 20I8). Kandungan magnesium stearate pada tablet juga berpengaruh terhadap kelembaban serbuk karena magnesium stearate dapat meningkatkan penguapan air di dalam oven sehingga menyebabkan bobot serbuk menjadi berkurang dan nilai kelembaban juga meningkat. Selain itu, suhu dan kelembaban ruangan juga menjadi faktor meningkatnya nilai kelembaban serbuk. Semakin tinggi suhu ataupun kelembaban ruangan, maka semakin tinggi pula kandungan lembab serbuk dikarenakan sifat dari serbuk effervescent yang higroskopis (Elisabeth $\mathrm{V}$ et al., 2018).

\section{Evaluasi Tablet Effervescent}

Tablet dibuat menjadi 4 formula, dimana tablet yang dihasilkan pada tiap formula adalah 50 tablet effervescent, dengan total keseluruhan tablet yaitu 200 tablet effervescent. Tablet effervescent pada tiap formula dilakukan evaluasi tablet meliputi evaluasi organoleptik, keseragaman bobot, kekerasan tablet, kerapuhan tablet dan waktu larut tablet. Proses evaluasi dilakukan untuk menjamin bahwa tablet sesuai dengan ketentuan persyaratan tablet yang baik (Syahrina D \& Noval, 202I).

Hasil evaluasi organoleptis dilakukan untuk mengidentifikasi karakteristik dari setiap formula yang dibuat (Noval, 202I). Dari hasil yang didapatkan tidak ada pengaruh dari semua formula berdasarkan dari bentuk, warna, bau dan rasa. Dimana bentuk yang dihasilkan dari semua formula berbentuk bulat pipih, memiliki bau khas, berwarna coklat muda dan memiliki rasa sedikit pahit. Hasil ini sejalan dengan penelitian yang dilakukan oleh (Syahrina D \& Noval, 202I) bahwa hasil evaluasi organoleptis kemungkinan besar tidak ada pengaruh terhadap perbedaan formula, namun memberikan identifikasi dari setiap formula.

Uji keseragaman bobot bertujuan untuk mengetahui bobot tablet yang dihasilkan serta menjadi acuan terhadap zat aktif yang terkandung dari sediaan tablet (Yulianti D.A \& Sutoyo S, 202I). Batas penyimpangan tablet dengan bobot rata-rata $300 \mathrm{mg}$ menurut ketentuan Farmakope Edisis III yaitu kolom A 7,5\% dan kolom B I5\%. Menurut persyaratan Farmakope Edisi III yaitu tidak boleh lebih dari 2 tablet yang menyimpang 
dari kolom A dan tidak boleh ada I tablet yang menyimpang dari kolom B (Anonim, 1979). Hasil perhitungan keseragaman bobot tablet effervescent pada $\mathrm{FI}$ dan $\mathrm{F} 2$ tidak terdapat penyimpangan bobot tablet. Adapun pada F3 dan F4 terdapat penyimpangan bobot tablet yaitu pada F3 terdapat 6 tablet yang menyimpang dari kolom A, dan pada F4 terdapat 4 tablet yang menyimpang dari kolom A dan I tablet yang menyimpang dari kolom $B$. penyimpangan bobot tablet dapat disebabkan oleh faktor distribusi ukuran serbuk dan sifat alir serbuk (Ramadhani R.F, 2018). Pada F4 kecepatan alir yang dihasilkan belum memenuhi persyaratan, hal tersebut berpengaruh terhadap proses pencetakan tablet pula sehingga tablet yang dihasilkan menjadi tidak seragam (Tanjung Y.P dan Puspitasari I, 2019). Faktor lainnya yang menyebabkan penyimpangan bobot tablet yaitu terdapat partikel yang menempel pada punch dan die disebabkan tablet yang mulai lembab karena sifat dari tablet effervescent yang higroskopis (Tanjung Y.P dan Puspitasari I, 2019).

Uji kekerasan tablet dilakukan untuk mengetahui kekuatan dan ketahanan tablet terhadap benturan atau tekanan mekanik saat proses produksi hingga distribusi obat (Syahrina D \& Noval, 202I). Nilai kekerasan tablet yang baik berkisah antara $4-8 \mathrm{~kg}$ (Apsari P.A et al, 2018). Berdasarkan penelitian hasil uji kekerasan tablet menunjukkan pada $\mathrm{FI}$ yaitu 3,3 kg, F2 yaitu 2 kg, F3 yaitu 5,6 kg dan F4 yaitu 2,6 kg. berdasarkan hasil tersebut pada F3 memenuhi kekerasan tablet yang baik, adapun pada FI, F2 dan F4 tidak memenuhi kekerasan tablet karena tidak sesuai dengan rentang kekerasan tablet yang baik yaitu 4-8 kg (Apsari P.A et al, 2018). Kekerasan tablet dapat dipengaruhi oleh tekanan kompresi saat pencetakan, semakin besar tekanan kompresi yang diberikan saat pencetakan maka nilai kekerasan tablet juga akan semakin tinggi (Noval \& Malahayati, 202I). Selain itu, kekerasan tablet juga dipengaruhi oleh sifat dari formula effervescent yang higroskopis yang menyebabkan tablet mudah lembab dan menyebabkan kekerasannya menurun (Tanjung Y.P dan Puspitasari I, 2019).

Uji kerapuhan tablet bertujuan untuk menggambarkan kekuatan tablet yang berhubungan dengan ikatan partikel pada tepi ataupun permukaan tablet. Semakin besar nilai kerapuhan tablet, maka semakin besar pula masa tablet yang hilang. Nilai kerapuhan tablet yang baik yaitu kurang dari 1\%. Kerapuhan tablet yang tinggi akan mempengaruhi kandungan zat aktif dari tablet (Putri Y.K \& Husni P, 2018). Berdasarkan penelitian hasil uji kerapuhan tablet menunjukkan pada FI dan F2 yaitu I,03\%, F3 yaitu $0,66 \%$ dan $\mathrm{F} 4$ yaitu $0,33 \%$. Nilai kerapuhan pada F3 dan F4 memenuhi persyaratan kerapuhan tablet yang baik, adapun pada FI dan F2 tidak memenuhi persyaratan karena nilai kerapuhan yang dihasilkan lebih dari I\%. Nilai kerapuhan tablet dipengaruhi oleh konsentrasi PVP sebagai bahan pengikat, maka akan semakin tinggi kekerasan tablet dan semakin rendah nilai kerapuhannya. Faktor lainnya yang juga berpengaruh terhadap kerapuhan tablet yaitu suhu dan kelembaban ruangan, dimana tablet effervescent akan mudah lembab dan terurai pada suhu dan ruangan yang tinggi (Tanjung Y.P dan Puspitasari I, 2019).

Uji waktu larut tablet dilakukan untuk menggambarkan waktu yang dibutuhkan tablet untuk larut sempurna dalam air dengan volume tertentu (Hermanto, 2019). Waktu larut yang baik untuk tablet effervescent yaitu kurang dari 5 menit (Syahrina D \& Noval, 2021). Pelarutan tablet effervescent diawali penetrasi air ke dalam pori-pori tablet yang kemudian menimbulkan 
reaksi effervescent antara zat asam dan zat basa yang menghasilkan gas karbondioksida untuk proses pelarutan tablet effervescent (Syahrina D \& Noval, 2021). Berdasarkan penelitian hasil uji waktu larut tablet menunjukkan pada FI yaitu 01.99 menit, F2 yaitu 02.25 menit, F3 yaitu 02.70 dan F4 yaitu 04.03 menit. Hasil pada semua formula sudah memenuhi persyaratan waktu larut tablet yang baik yaitu kurang dari 5 menit. Namun formua yang memilki waktu larut tercepat yaitu FI dengan waktu 0I.99 menit, semakin cepat kelarutan tablet effervescent maka akan semakin baik (Syahrina D \& Noval, 2021). Waktu larut tablet effervescent disebabkan oleh faktor reaksi effervescent yang terlalu dini saat proses pencetakan, sehingga menyebakan daya atau reaksi effervesting menjadi berkurang. Selain itu, kelembaban udara saat proses pencetakan juga berpengaruh karena akan meningkatkan penurunan kualitas tablet terutama pada daya larut dari tablet effervescent (Noorjannah \& Noval, 2020) (Noval \& Rosyifa, 202I).

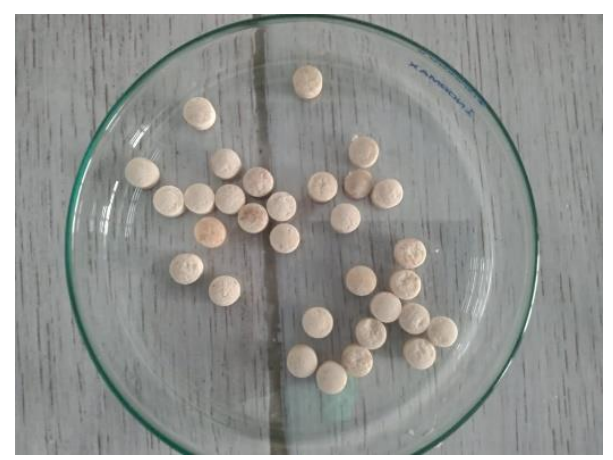

Gambar 2. Tablet Effervescent

\section{KESIMPULAN}

Berdasarkan hasil evaluasi parameter utama yaitu evaluasi waktu larut sediaan tablet Effervescent Ekstrak buah tampoi didapatkan formulasi yang paling ideal yaitu FI dengan konsentrasi PVP K30 yaitu 0,5 mg dihasilkan waktu larut selama 01.99 menit.

\section{UCAPAN TERIMA KASIH}

Peneliti mengucapkan terimakasih yang sebesarbesarnya kepada Kementrian Riset dan Teknonologi atau Badan Riset dan Inovasi Nasional Republik Indonesia yang mendanai penelitian ini melalui skema hibah Penelitian Dosen Pemula di tahun 202I.

\section{REFERENSI}

I. Noval, N., Kuncahyo, I., Pratama, A. F. S., Nabillah, S., \& Hatmayana, R. (202I). Formulasi Sediaan Tablet Effervescent dari Ekstrak Etanol Tanaman Bundung (Actionoscirpus grossus) sebagai Antioksidan. Jurnal Surya Medika (JSM), 7(I), 128139.

2. Haegens, R. (2000). Taxonomy, phylogeny, and biogeography of Baccaurea, Distichirhops, and Nothobaccaurea (Euphorbiaceae). Journal of Plant Taxonomy and Plant Geography, Supplement 12

3. Haryono, I. A., Noval, N., \& Nugraha, B. (202I). Formulasi Buah Tampoi (Baccaurea macrocarpa) dalam Sediaan Masker Gel sebagai Antiaging. Jurnal Surya Medika (JSM), 6(2), I02-I I0.

4. Tirtana, R. D. (2013). Pengaruh Sinar Radiasi Ultraviolet (Uv) Terhadap Antibakteri Sirih Merah (Piper Crocatum) Untuk Menekan Laju Pertumbuhan Bakteri Streptococcus Mutans Secara In Vitro (Doctoral dissertation, UNIVERSITAS AIRLANGGA).

5. Akhmadi, Noor Roufiq dan Sumarmiyati. 2015. Eksplorasi dan Karakteristik Buah Kapul (Beccaurea Macrocarpa) di Kabupaten Kutai Barat, Kalimantan Timur. Jurnal Pros Sem Nas Masy BioDIV Indon, Vol I, Nomor 4, Halaman: 923-929.

https://smujo.id/files/psnmbi/M0 104/M0 10448.pdf\# : :text=2013)\%20menunjukkan\%20tanaman\%20ka pul\%20memiliki,alkaloid\%2C\%20dan\%20flavanoid\% 20yang\%20aktif.

6. Nastiti, K., Noval, N., \& Kurniawati, D. (202I). Uji Aktivitas Antioksidan Kombinasi Infusa Daun Sirih (Piper betle L), Ekstrak Etanolik Tanaman Bundung (Actinuscirpus grossus) dan Kulit leruk Nipis (Citrus aurantifolia). Jurnal Surya Medika (JSM), 7(I), II5-122.

7. Noval, N. (202I). Formulasi dan Teknologi Sediaan Solida (R. Fitria (ed.); Pertama). CV. Mitra Cendekia Media. 
8. Lestari, A. B. S. dan Natalia L., 2007, Optimasi Natrium Sitrat dan Asam Fumarat seabagi Sumber Asam dalam Pembuatan Granul Effervescent Ekstrak Temulawak (Curcuma Xanthorrhiza Roxb) secara Granulasi Basah, Majalah Farmasi Indonesia, I8 (I), 2I-28.

9. Noval, N., \& Malahayati, S. (202I). TEKNOLOGI PENGHANTARAN OBAT TERKENDALI.

10. Syahrina, D., \& Noval, N. (2021). Optimasi Kombinasi Asam Sitrat dan Asam Tartrat sebagai Zat Pengasam pada Tablet Effervescent Ekstrak Ubi Jalar Ungu (Ipomoea batatas L). Jurnal Surya Medika (JSM), 7(I), I56- I72.

II. Indartantri, K. B., Noval, N., \& Oktaviannoor, H. (202I). Formulasi dan Evaluasi Floating System Tablet Difenhidramin $\mathrm{HCl}$ Menggunakan Kombinasi Matriks HPMC K4M dan $\mathrm{Na}$. CMC. Jurnal Surya Medika (JSM), 7(I), I07-I I4.

12. Novia, N., \& Noval, N. (202I). Pengaruh Kombinasi Polimer Polivinil Pirolidon dan Etil Selulosa terhadap Karakteristik dan Uii Penetrasi Formulasi Transdermal Patch Ekstrak Bawang Dayak (Eleutherine palmifolia (L). Jurnal Surya Medika (JSM), 7(I), I73-I84.

13. Putra et al. (20/9). Penggunaan Polivinil Pirolidon (PVP) sebagai bahan pengikat pada formulasi tablet ekstrak daun sirih (Piper betle L.). Jurnal Farmasi Udayana. Vol.8 no.I.

14. Hermanto. (2019). Pengaruh PVP dan HPMC sebagai bahan pengikat terhadap sifat fisik tablet effervescent kombinasi perasan buah naga merah (Hyolecerus polyrhizus) dan tomat (Lycopersicum escunlentum MILL). Karya Tulis Ilmiah. Politeknik Harapan Bersama. Tegal.

15. Fatikha, N. (2020). Pengaruh pengikat PVP, pati biji durian termodifikasi asam dan kombinasi terhadap uji sifa fisik granul effervescent perasan daun seledri (Apium graveolens L.). Karya Tulis IImiah. Politeknik Harapan Bersama. Tegal.

16. Ramadhani, R.F. (2018). Formulasi tablet effervescent ekstrak kulit buah delima (Punica granatum $L$. var.album) dengan variasi asam sitrat dan asam tartrat. Skripsi. Universitas Darussalam. Gontor.

17. Noval, N., Nugraha, D. F., Nastiti, K., Syahrina, D., \& Novia, N. (202l). Local Natural Product Development in the Era of Covid 19 Pandemic. Indonesia Berdaya, 2(2), I33-I40.
18. Noval, N., Appriliani, R., \& Oktaviannoor, H. (202I). Evaluasi Pengaruh Konsentrasi Pati Biji Cempedak (Artocarpus champeden) sebagai Bahan Pengisi pada Formulasi Tablet Paracetamol. Jurnal Surya Medika (JSM), 6(2), I I I-I I8.

19. Noval, N., \& Rosyifa, R. (202I). Dispersi Padat untuk Peningkatan Laju Disolusi Natrium Diklofenak dengan Variasi Konsentrasi Polivinil Pirolidon K30. Jurnal Surya Medika (JSM), 6(2), $94-$ I0I.

20. BPOM RI. (20I5). Surat Edaran No. HK.04.4.42.I I.I5.I490. Badan POM RI. Jakarta

21 . Elisabeth $\mathrm{V}$ et al. (2018). Formulasi sediaan granul dengan bahan pengikat pati kulit pisang Goroho (Musa acuminafe L.) dan pengaruhnya pada sifat fisik granul. Jurnal Ilmiah Farmasi-UNSTRAT. Vol.7, no.4.

22. Yulianti, D. A., \& Sutoyo, S. (202I). Formulasi Tablet Effervescent Ekstrak Daun Katuk (Saoropus androgynous L. Merr.) dengan Variasi Konsentrasi Asam dan Basa. Jurnal Farmasi Sains dan Terapan, 8(I), 34-40.

23. Anonim. (1979). Farmakope Indonesi, Edisi III. Departemen Kesehatan Republik Indonesia. Jakarta

24. Tanjung, Y. P., \& Puspitasari, I. (20I9). FORMULASI DAN EVALUASI FISIK TABLET EFFERVESCENT EKSTRAK BUAH MENGKUDU (Morinda citrifolia L.). Farmaka, I 7(I), I-I4.

25. Apsari, P. A., Sari, D. N. E., Kusuma, A. P., \& Indrati, O. (20I8). Effervescent Tablet Formulation Melinjo Seed Extract (Gnetum gnemon L.) Using PEG 6000 As Lubricant and Citric Acid-Tartaric Acids As Acid Sources. EKSAKTA: lournal of Sciences and Data Analysis, I8(I), 30-4I.

26. Putri, Y. K., \& Husni, P. (20/8). ARTIKEL TINIAUAN: PENGARUH BAHAN PENGIKAT TERHADAP SIFAT TABLET. Farmaka, I6(I), 33-40.

27. Nooriannah, N., \& Noval, N. (2020). Uji Disolusi Terbanding Antara Sediaan Tablet Ramipril Generik Dan Bermerek. lournal of Pharmaceutical Care and Sciences, I ( I), 45-54. 